\title{
Digital Supervision of Assimilated Inmates in the Covid-19 Pandemic Period
}

\author{
Markus Marselinus Soge* \\ Politeknik Ilmu Pemasyarakatan \\ (Polytechnic of Correctional Science) \\ Kementerian Hukum dan HAM RI \\ Depok, Indonesia \\ marcel@poltekip.ac.id \\ ORCID: 0000-0002-0012-1721
}

\begin{abstract}
The Covid-19 pandemic has forced a breakthrough in public policy, one of which is the policy of assimilation of inmates to avoid the potential impact of the spread of Covid-19 in penitentiaries. The public concern of the assimilation policy is how to supervise the inmates. This paper intended to discuss how to supervise assimilated inmates especially during the Covid-19 pandemic. The author uses a normative legal research method with a focus on secondary data and uses the document study as data collection technique. Inmates have the right to receive coaching and guidance from the state to help them realize their mistakes and correct themselves. Inmates who have met the requirements entitled to get assimilation, which is a stage of coaching by integrating inmates into the life of society. Supervision of assimilated inmates during the Covid-19 pandemic is carried out, among others, by Correctional Centers in Lampung, the Polewali Correctional Center, and the Denpasar Correctional Center. It concluded that the method to supervise the assimilated inmates during the Covid-19 pandemic is digital supervision online with various means such as telephone, short message service, WhatsApp, and video call.
\end{abstract}

Keywords—supervision, assimilation, inmates, covid-19

\section{INTRODUCTION}

The Corona Virus Disease 2019 (Covid-19) pandemic in various countries has forced a breakthrough in various public policies, all of which are solely in the interests of the wider community. One aspect of government affected by Covid-19 is the field of law specifically the implementation of criminal law for those who have been sentenced by the court to undergo imprisonment and placed in a penitentiary.

Public policies taken by the government to prevent the spread of Covid-19 are implementing a clean and healthy way of life by washing hands and wearing masks frequently, maintain physical distance between people, and large-scale social restrictions that are realized with the closure of schools and workplaces, limiting religious activities, and restrictions on activities in public places or facilities [1].

One of the state facilities that are very vulnerable to the spread of Covid-19 is the penitentiary because it is inhabited by inmates of various types of criminal acts who together live and will continue to crowd the penitentiary cells.

Being aware of the potential impact of the spread of Covid-19 in the penitentiary because it does not allow for social restrictions such as workplace vacations, restrictions on activities in the penitentiary which are public facilities, and limiting the distance between people, the government takes the assimilation policy.

The assimilation, namely removing inmates who have fulfilled the requirements from within the penitentiary by integrating them into the community. Data up to June 2020 shows that there are 179,752 inmates throughout Indonesia, and inmates who carry out assimilation are 36,681 adults and 940 children [2] or approximately $21 \%$ of the total inmates.

The policy of assimilation during the Covid-19 pandemic has caused anxiety because of the lack of information about supervising mechanism for inmates so that they don't commit crimes again [3]. The main concern of the public regarding the assimilation policy, which is also a problem in this paper, is how to supervise assimilated inmates especially during the Covid-19 pandemic?

In seeking answers to the problem, there are three article that discuss inmates and Covid-19 pandemic. First, an article on "Strategic Steps to Prevent the Covid-19 Pandemic in Indonesian Penitentiary", which focuses on the steps taken by the Ministry of Law and Human Rights in preventing Covid19 in the penitentiary [4]. Second, an article on "Supervision of Inmates on Parole by Community Advisors, Challenges and Alternative Solutions", which focuses on obstacles in the supervision of inmates who are undergoing parole [3]. Third, an article on "Controversy over the Release of Inmates Amid the Covid-19 Pandemic", which focuses on the controversy and impact of the policy of releasing inmates during the Covid-19 pandemic [5].

The difference between this paper and the previous paper is the discussion of how to supervise assimilated inmates, especially during the Covid-19 pandemic. Supervision is very important because the status of inmates is not the same as a person who has finish serving a sentenced period. Supervision is also limited by social restriction policies to reduce or even eliminate physical encounters between correctional officers with these inmates.

\section{METHOD}

To answer the research question, the author uses a normative legal research method that examining the 
enactment of a legal norm, focuses on secondary data, and uses the document study as data collection technique.

Secondary data are in the form of legal and nonlegal materials. Legal materials namely laws, policies, research results, expert opinions [6], and nonlegal materials namely online media coverage. Document studies of secondary data in the form of online media coverage can be carried out through online searches [7].

Mass media coverage including online media is a form of media responsibility to disseminate and fulfill public information needs. The mass media acts as the storyteller of an event by maintaining the quality of the news so that the information submitted is credible and objective. Online media portals are often used as a source of reference for the community because they are always up to date in reporting every event that occurs in society [8]

\section{DISCUSSION}

Studies on how to supervise assimilated inmates during the Covid-19 pandemic are limited to discussion of the implementation of legal provisions by government agencies supported by evidence of implementation in the form of online media coverage. The practical benefit of this paper is to help the government and society in monitoring inmates who carry out assimilation during the Covid-19 pandemic digitally, while the theoretical benefit is to develop methods of monitoring or social control for inmates who carry out assimilation.

\section{A. Social Reintegration of Inmates}

Inmates have the right given by laws and regulations to receive guidance from the state, both inside and outside of the penitentiary. As a law violator, the process of enforcing criminal law against the perpetrator starts from the investigation stage, then the prosecution, and ends at the court trial. After the judge's decision in the form of imprisonment against the perpetrator, it is then submitted to the government by preparing coaching facilities for inmates, namely the penitentiary or correctional institution.

The purpose of placing inmates in a correctional institution is to coach and guide from the state to its citizens who have been wrong and have committed irregularities so that the inmates can realize their mistakes and correct themselves. In the future, after completing their sentenced period they can be accepted again and integrated with society even further can provide useful contributions to society. This is the concept of social reintegration which is the basic philosophy of the correctional institution [9].

The concrete form of the implementation of coaching and guidance to inmates is through personality development and self-reliance development. Personality development is carried out by fostering religious awareness, awareness of the nation and state, intellectual ability, legal awareness, and integrating oneself with society. Meanwhile, self-reliance development is carried out by providing skills to support independent businesses, small industries, agricultural and plantation activities, and skills that are developed according to their respective talents [10].

\section{B. Assimilation Supervision}

Following the provisions of the regulations, inmates who have met the requirements, namely serving half of their sentenced period, having good behavior, and followed a good coaching program in the correctional institution are entitled to get assimilation [11]. The implementation of assimilation is by integrating inmates into the life of the society. However, before the process is carried out, there are complete documents that must be attached including a statement from the inmates not to run away and not to commit any illegal acts [12].

The state certainly will not just let go of the inmates who undergo the assimilation program. In other words, the state exercises strict supervision of the assimilation of inmates through state-owned instruments and resources. From an academic perspective, supervision is based on the theory of social control which views every human being as a creature who has the freedom to choose actions to obey or violate applicable rules, therefore techniques and strategies are needed in regulating human behavior to bring it to adaptation or obedience to the rules of society [13]. Thus, supervision is a mechanism to prevent social deviations, encourage, and direct people to behave and following prevailing norms and values [14].

Considering the legal status of an inmate is not a free person but is undergoing coaching and guidance in the form of assimilation, the person must have full awareness that he is being supervised. Supervision of assimilated inmates in the prevention and control of Covid-19 is carried out by the correctional center [11]. Supervision by the correctional center demands high discipline from inmates not to violate the conditions given and requires inmates to report themselves and explain what they did while outside [15].

Before the Covid-19 pandemic, assimilation supervision was carried out through physical meetings between officers from the correctional center with inmates and their families, either with the provision of compulsory reporting for inmates to the correctional center or by visiting the residence of the respective address [3]. However, with the Covid-19 pandemic in the form of a social restriction policy so that physical gatherings were limited, a policy breakthrough was made with digital supervision.

The legal basis for digital supervision of assimilated inmates during the Covid-19 pandemic, namely: (1) Regulation of the Minister of Law and Human Rights Number 10 of 2020 concerning the Terms of Providing Assimilation and Integration Rights for Inmates and Children in the Context of Preventing and Combating the Spread of Covid-19, (2) Decree of the Minister of Law and Human Rights Number M.HH.19.PK 01.04 of 2020 concerning the Removing and Release of Inmates and Children through Assimilation and Integration in the Context of Prevention and Control of Covid19, and (3) Circular of the Director-General of Corrections Number PAS-516.PK.01.04.06 of 2020 concerning the Mechanism of Implementing Ministerial Regulations Law and Human Rights Number 10 of 2020.

The method of digital supervision of assimilated inmates during the Covid-19 pandemic, according to the legal provisions above, is carried out online by contacting inmates using the media telephone, short message service or SMS, WhatsApp or WA, and video call according to schedule and 
filling out the supervision report [16]. Online supervision aims to ensure the presence of inmates, daily activities, relationships with family and the environment, and their health conditions [17].

The implementation of the digital supervision of assimilated inmates during the Covid-19 pandemic has been carried out by the correctional center, among others, namely:

- Correctional Centers in Lampung

- Supervision of 1,579 adult and child inmates undergoing assimilation for reasons of preventing and overcoming Covid-19 in the working area of all Correctional Center in Lampung was carried out via video call, telephone, and SMS [18].

\section{- The Polewali Correctional Center}

- Supervision of 163 inmates undergoing assimilation and integration due to Covid-19 in the working area of the Polewali Correctional Center was carried out via video call, SMS, telephone, and WA [19].

- The Denpasar Correctional Center

- Supervision of 236 inmates undergoing assimilation for reasons of preventing Covid-19 in the working area of the Denpasar Correctional Center was carried out online by telephone, SMS, WA, and video call [20].

By relying on the use of internet networks, information and communication technology, those correctional centers supervise assimilated inmates especially during the Covid-19 pandemic uses online methods with various means such as telephone, SMS / WA / video call or conference [5].

Online digital supervision with various means is also a technique and strategy in regulating the behavior of inmates to conform to society's rules, prevent social deviation, and direct inmates to behave and following prevailing norms and values so that inmates do not commit crimes anymore.

\section{CONCLUSION}

The concept of social reintegration of inmates means that inmates have the right to receive guidance from the state with the aim that the inmates can realize their mistakes and improve themselves. After completing their sentenced period they can be accepted again and integrated with society and can even make useful contributions to society.

Assimilation is a stage of coaching for inmates by integrating inmates with society. Assimilation is given after the inmates fulfill the requirements to undergo half of their sentenced period, having good behavior, and followed a good coaching program in the penitentiary. The implementation of assimilation during the Covid-19 pandemic was supervised by the correctional center.

The method to supervise the assimilated inmates during the Covid-19 pandemic, according to Regulation of the Minister of Law and Human Rights Number 10 of 2020 and its technical provisions, is digital supervision. Correctional Centers in Lampung, the Polewali Correctional Center, and the Denpasar Correctional Center have carried out digital supervision online with various means such as telephone, SMS, WA, and video call.

\section{REFERENCES}

[1] Peraturan Pemerintah Nomor 21 Tahun 2020 Tentang Pembatasan Sosial Skala Besar Dalam Rangka Percepatan Penanganan Corona Virus Disease 2019 (Covid-19) [Government Regulation Number 21 of 2020 concerning Large-Scale Social Restrictions in the Context of Accelerating Handling of Corona Virus Disease 2019 (Covid-19)], and https://covid19.go.id/edukasi/.

[2] Yasonna Laoly, National Seminar Series Criminal Law And Criminology \#2 MAHUPIKI, "Kebijakan Pembebasan Narapidana" ["Inmates Release Policy”], 29 Juni 2020.

[3] Fariha Suci Rahmasari, "Pengawasan Narapidana Pembebasan Bersyarat Oleh Pembimbing Kemasyarakatan Tantangan dan Alternatif Penyelesaiannya" ["Supervision of Inmates on Parole by Community Advisors, Challenges and Alternative Solutions"], Justitia: Jurnal Ilmu Hukum dan Humaniora Volume 7 Number 2 of 2020, p. 368-379, in press.

[4] Risyal Hardiyanto Hidayat, "Langkah-Langkah Strategis Untuk Mencegah Pandemi Covid-19 Di Lembaga Pemasyarakatan Indonesia" ["Strategic Steps to Prevent the Covid-19 Pandemic in Indonesian Penitentiary"], Jurnal Pendidikan Kesehatan Volume 9 Number 1 April 2020 , p. 47 , p. 43 , in press.

[5] Trias Palupi Kurnianingrum, "Kontroversi Pembebasan Narapidana Di Tengah Pandemi Covid-19" "“Controversy over the Release of Inmates Amid the Covid-19 Pandemic'], Info Singkat Kajian Singkat Terhadap Isu Aktual Dan Strategis Volume XII Number 8/II/Puslit/April/2020, p.1, p.4, in press.

[6] Amiruddin and Prof. Zainal Asikin, Pengantar Metode Penelitian Hukum [Introduction to Legal Research Methods], Jakarta: Rajawali Pers, 2016, p.118-119, p.135.

[7] Stephen Elias, Legal Research How to Find \& Understand the Law, $18^{\text {th }}$ Edition, California: Nolo, 2018, p. 27.

[8] Praptika Handayani and Anang Hermawan, "Kredibilitas Portal Berita Online Dalam Pemberitaan Peristiwa Bom Sarinah Tahun 2016 (Analisis Isi Portal Berita Detik.Com dan Kompas.Com Periode 14 Januari-14 Februari 2016)" ["Online News Portal Credibility in Reporting the 2016 Sarinah Bombing Incident (Content Analysis of the Detik.Com News Portal and Kompas.Com for the Period of January 14-February 14 2016)"'], Jurnal Komunikasi Volume 12 Number 1 October 2017, p. 53, p. 55, in press.

[9] Iqrak Sulhin, 3rd International Conference on Archipelago Philosophy, Faculty of Philosophy, Gadjah Mada University, "Filsafat Pemasyarakatan dan Paradoks Pemenjaraan di Indonesia" ["Philosophy of Prison and the Paradox of Imprisonment in Indonesia"], 10-11 November 2015.

[10] M. Ali Aranoval, Refleksi 50 Tahun Sistem Pemasyarakatan Anatomi Permasalahan dan Upaya Mengatasinya, "Partisipasi Masyarakat Dalam Pelaksanaan Pemasyarakatan" [Reflections on 50 Years of Correctional System Anatomy Problems and Efforts to Overcome Them, "Community Participation in Correctional Implementation"], Jakarta: Center for Detention Studies, 2015, p.1189-190.

[11] Peraturan Pemerintah Nomor 32 Tahun 1999 Tentang Syarat dan Tata Cara Pelaksanaan Hak Warga Binaan Pemasyarakatan [Government Regulation Number 32 of 1999 concerning Terms and Procedures for the Implementation of the Rights of Correctional Assistants], Article 37 .

[12] Peraturan Menteri Hukum dan Hak Asasi Manusia Republik Indonesia Nomor 10 Tahun 2020 Tentang Syarat Pemberian Asimilasi dan Hak Integrasi Bagi Narapidana Dan Anak Dalam Rangka Pencegahan dan Penanggulangan Penyebaran Covid-19 [Regulation of the Minister of Law and Human Rights of the Republic of Indonesia Number 10 of 2020 concerning Conditions for Granting Assimilation and Integration Rights for Inmates and Children in the Context of Preventing and Combating the Spread of Covid-19], Article 1 number 3, Article 3, Article 4, and Article 2 paragraph ( 1).

[13] Anang Priyanto, Pengantar Kriminologi PKNI 4209/Modul 1 [Introduction to Criminology PKNI 4209/Module 1], pp.1.30-1.31, http://repository.ut.ac.id/4193/1/PKNI4209-M1.pdf

[14] H.M.Natsir, Kriminologi Dan Teori-Teori Hukum [Criminology and Legal Theories], Mataram: Pustaka Bangsa, 2016, p.20.

[15] Iqrak Sulhin, Diskontinuitas Penologi Punitif Sebuah Analisis Geneologis Terhadap Pemenjaraan [Punitive Penological Discontinuity A Geneological Analysis of Imprisonment], Jakarta: Prenadamedia Group, 2016, p.111. 
[16] Surat Edaran Direktur Jenderal Pemasyarakatan Nomor PAS516.PK.01.04.06 Tahun 2020 Tentang Mekanisme Pelaksanaan Peraturan Menteri Hukum dan Hak Asasi Manusia Nomor 10 Tahun 2020 [Circular of the Director General of Corrections Number PAS516.PK.01.04.06 of 2020 concerning the Mechanism of Implementing Regulation of the Minister of Law and Human Rights Number 10 of 2020], Item 5b number 5) b).

[17] Direktorat Bimbingan Kemasyarakatan dan Pengentasan Anak dan Center for Detention Studies, Pedoman Pelaksanaan Penelitian Kemasyarakatan Dan Pendampingan Secara Daring Serta Pembimbingan Dan Pengawasan Klien Asimilasi Dan Integrasi Dalam Rangka Pencegahan \& Penanggulangan Penyebaran Covid-19 [Directorate of Community Guidance and Child Eradication and Center for Detention Studies, Guidelines for Conducting Community Research and Online Assistance as well as Assimilation and Integration Client Guidance and Supervision in the context of Preventing \& Combating the Spread of Covid-19], Jakarta: Direktorat Jenderal Pemasyarakatan Kementerian Hukum dan HAM RI, April 2020, p.1718.

[18] Pengawasan Napi dan Anak Program Asimilasi Melalui Video Call [Supervision of Inmates and Children Assimilation Program Through Video Calls], https://www.lampost.co/berita-pengawasan-napi-dananak-program-asimilasi-melalui-video-call.html, and Lampung Lepaskan 1.579 Napi Asimilasi [Lampung Releases 1,579 Assimilated
Inmates], https://republika.co.id/ berita/q8s4an327/lampung-lepaskan1579-napi-asimilasi.

[19] Klien Program Asimilasi dan Integrasi PB/CB Diawasi Pembimbing Kemasyarakatan PK Bapas Polewali Melalui Daring [Clients of PB / CB Assimilation and Integration Program Supervised by Community Guidance of PK Bapas Polewali Online], https://sulbar.kemenkumham.go.id/berita-kanwil/berita-upt/3522-163klien-program-asimilas-dan-integrasi-pb-cb-diawasi-pembimbingkemasyaratan-pk-bapas-polewali-melalui-daring, and Bapas Polewali Awasi 163 Klien Program Asimilasi Rumah dan Integrasi PB/Cb Via Daring [Bapas Polewali Supervises 163 Clients of Home Assimilation and $\mathrm{PB} / \mathrm{CB}$ Integration Programs Via Online], https://makassar.tribunnews.com/ 2020/04/08/bapas-polewali-awasi163-klien-program-asimilasi-rumah-dan-integrasi-pbcb-via-daring.

[20] Bapas Denpasar Awasi Para Klien Asimilasi Secara Daring Akan Cabut Asimilasi Jika Melanggar [Bapas Denpasar Supervises Assimilation Clients Online Will Revoke Assimilation if Violated], https://bali.tribunnews.com/2020/04/07/ bapas-denpasar-awasi-paraklien-asimilasi-secara-daring-akan-cabut-asimilasi-jika-melanggar, and Bapas Denpasar Pantau 299 Klien Asimilasi Daring [Bapas Denpasar Monitors 299 Online Assimilation Clients], https://balitribune.co.id/content/bapas-denpasar-pantau-299-klienasimilasi-daring. 